\title{
Rola uniwersytetów ludowych w ekologicznej edukacji młodzieży wiejskiej
}

\begin{abstract}
Wstęp
Czynnikiem najważniejszym i tym, który najsilniej oddziaływał na człowieka i to nie tylko mieszkającego na wsi była dawniej przyroda. W przeszłości związek ten był silniejszy nawet, jeżeli chodzi o ludzi mieszkających w mieście. Nie były to bowiem wielkie aglomeracje, $\mathrm{z}$ którymi mamy do czynienia dzisiaj. Przyroda utrzymywała w silnej zależności od siebie wszelkie czlowiecze działanie, żywiła, dawała szczęście i uśmiercała, kształtowała jego zasadniczy pogląd na świat, czynna ona była nawet przy stwarzaniu pierwotnych religii. W klęskach uczył się jednak człowiek cierpliwości i przetrzymywania. Wiedział, ze po burzy przyjdzie ładna pogoda, po zimie wiosna, po latach nieurodzaju rok urodzajny. Zdobywał człowiek cenną społecznie równowagę, gwarantującą trwanie, zdobywał twórczą siłę ducha - optymizm, tę wiarę, że gdy się przetrwa złe, dojść się musi do lepszego. Człowiek nie łamał się, ale hartowałำ.

Codzienna możliwość obserwowania jak powstaje, rozwija, mnoży się i zamiera życie, porównywanie przebogatych form i sposobów życia roślinnego i zwierzęcego, wnioskowanie doświadczalne od przyczyn do skutków - rodziło myślenie. Twarde życie, namacalna łączność z przyrodą wyrabiały w człowieku wsi zmysł realizmu i rzeczowości².

Edukacja ekologiczna szeroko pojęta $\mathrm{z}$ całą swoją problematyką jest bliska Uniwersytetom Ludowym i ważna dla nich programowo ${ }^{3}$. Wiąże się ona zarówno

Z. KACZOR-JĘDRZYcKA, Edukacja ekologiczna - nasza tradycja i obowiqzek, w: „Polski Uniwersytet Ludowy" (19), Warszawa, kwiecień - maj 1993, s. 7.

2 Tamże, s. 7.

3 Ekologia - gr. oikos = dom, środowisko + logos = slowo, nauka, dziedzina biologii badająca wzajemne stosunki między organizmami a otaczającym je środowiskiem. (Słownik wyrazów obcych, PWN, Warszawa 1980, s. 176). Dziś najczęściej „ekologia” wiąże się z troską człowieka o środowisko naturalne, o ochronę tego środowiska, w którym człowiek żyje. Jednakże należy
\end{abstract}


z tradycjami, genezą, jak i samą istotą wychowawczą uniwersytetów ludowych oraz potrzebami dnia dzisiejszego i najbliższej przyszłości ${ }^{4}$.

W tradycji uniwersytetów ludowych dążenie do harmonijnego współżycia i współdziałania człowieka z przyrodą ma ugruntowaną czołową pozycję. Już twórca idei uniwersytetów ludowych, duński polityk, historyk i pedagog Mikołaj Fryderyk Seweryn Grundtvig (1783 - 1872), kreśląc w połowie XIX w. projekt duńskiej szkoły wyższej, silnie akcentował, iż jeden z nauczycieli powinien być człowiekiem, który „zwiedził własny kraj wzdłuż i wszerz, mając przy tym oczy szeroko otwarte. Ktoś taki musiałby wiedzieć o ludziach, ptakach i zwierzętach nie starając się ich wszystkich policzyć, odróżnić ziarno od plew, lecz nie stosować wagi i miary do życia, siły i urody ludzi”s. Kiedy indziej Grundtvig, przeciwstawiając wyższą szkołę ludową szkołom oficjalnym podkreślał, że szkoła ludowa będzie ,jednostronnie, jak i wszechstronnie duńska, wolna od wszelkiego szkolnego kursu, od szkolnych potraw, co odbierają apetyt i pewien jestem, że pomoże duńskiej młodzieży wstąpić na to niewielkie duńskie wzgórze, z którego widać piękne pola i łąki, na których wiele się kończy i wiele zaczyna, i to dopomoże o wiele lepiej niż rzucanie na głęboką wodę oceanu, by sprawdzić, czy zdoła powrócić on do tego niewielkiego lądu, zwanego Danią, i nie stracić ochoty, by go zamieszkiwać i budować" .

\section{Historia i specyfika Uniwersytetów Ludowych}

Za ojczyznę uniwersytetu ludowego uważana jest Dania. Cechowała się ona trudnym położeniem społeczno - polityczno - ekonomicznym w momencie rozkwitu nowej koncepcji oświatowej, która zaowocowała tą właśnie instytucją. Reakcja na określone trudności i jednoczesna próba ich przezwyciężania, zrodziły ideę stworzenia takiej instytucji, która umożliwiałaby zdobycie wiedzy i po-

tutaj dodać, że w edukacji ekologicznej najważniejszy powinien być właśnie czlowiek. Wynika stąd konieczność powiązania ekologii $z$ antropologią i to nie tylko tą pozostającą na poziomie naturalnym, a więc antropologią przyrodniczą, czy antropologią kultury. Warto jest w tym względzie odwołać się również do antropologii filozoficznej i biblijno - teologicznej, dającej spojrzenie na rolę człowieka, którą wyznaczył mu Stwórca. Człowiek bezpośrednio po stworzeniu został umieszczony w ogrodzie Eden (por. Rdz 2,8), aby ten ogród uprawiał i go doglądał (por. Rdz 2, 15), czyli aby troszczył się o świat i jego upiększanie. Człowiek czasami nadużywa tej władzy i ze stróża staje się drapieżnikiem wykorzystującym bezmyślnie zasoby świata. Temu ma zapobiegać właściwie pojęta ekologia. Jednakże należy tutaj pamiętać, że podmiotem w edukacji ekologicznej jest czlowiek i nie może on stawać się jej przedmiotem, a ekologia jaką́s ideologią, czy tylko hasłem polityków.

4 Z. KaCZOR-J̨̨DRZYCKA, art. cyt., s. 6.

Cyt. za Tamże, s. 6.

6 A. Bron-Wojciechowska, Grundtvig, Warszawa 1986, s. 212. 
szerzenie horyzontów myślowych dorosłym mieszkańcom wsi, głównie dorosłej młodzieży. Instytucją tą stał się uniwersytet ludowy, którego inicjatorem był M. F. S. Grundtvig, jak wspomnieliśmy. W kraju przemysłowo słabo rozwiniętym, wyzwalające się masy ludowe zaczęły sięgać po przewodnictwo w życiu politycznym, gospodarczym i kulturalnym. Zniesienie poddaństwa i uwłaszczenie chłopów w roku 1778 zadecydowało o upadku duńskiej szlachty. Wzrosła natomiast rola mas chłopskich, rozwijających swe samodzielne gospodarstwa ${ }^{7}$.

Wiek XIX w Europie to - obok licznych ruchów o charakterze społeczno - politycznym - również okres wzmożonego zainteresowania kulturą i kreowaniem jej w oparciu o wartości związane $z$ narodem, $z$ ludem. Zainteresowanie to, jak pisze E. Maciąg, przybierało różnorodne formy, zazwyczaj jednak przejawiało się tendencjami o charakterze oświatowym ${ }^{8}$.

Bezpośrednim impulsem podjęcia pracy nad zorganizowaniem nowego typu szkoły na wyższym poziomie dla młodzieży wiejskiej - była obserwacja angielskiego systemu oświatowego. Grundtvig przebywał kilkakrotnie w Anglii i ten pobyt pozwolił mu na obserwację systemu wychowawczego oraz kształcenia w szkołach o charakterze internatowym ${ }^{9}$. Wnikliwa obserwacja i pogłębione studia sprowokowały niejako Grundtviga do przemyśleń na temat edukacji, w ramach której, podobnie jak w systemie angielskim, nacisk położony byłby zarówno na przekazywanie wychowankom informacji, jak i na kształtowanie charakteru jednostki oraz kreowanie określonych postaw społecznych. Realizacji tej idei miało służyć specjalne wychowanie, szczególnie przystosowana szkoła, która miałaby pomóc swoim wychowankom w kształtowaniu ich światopoglądu, w przygotowaniu do świadomego uczestnictwa w życiu społecznym. Tak rozumiany system oświatowo - wychowawczy miał być charakterystycznym elementem uniwersytetu ludowego. Miał on kształtować nie tylko indywidualnego człowieka, ale określone postawy społeczne wyznaczające nowe tory funkcjonowania społeczności lokalnych ${ }^{10}$.

O powstaniu uniwersytetów ludowych ostatecznie zadecydowały względy polityczne. Grundtvigowską ideę wyższej uczelni podjęły patriotyczne koła Duńczyków, szukające środków zaradczych przeciw germanizacji i ze szczególnym uwzględnieniem południowych obszarów Jutlandii. W obliczu takiej sytuacji powstał już w 1844 r. pierwszy uniwersytet ludowy, według projektu Grundtviga i przy współpracy Christiana Flora, w Rodding na granicy niemieckiej. Istniał on jednak krótko i po przyłączeniu południowych terenów Danii do Niemiec

\footnotetext{
E. GaRBACIK, Wieś duńska dawniej i dziś, Kraków 1946, s. 40.

8 E. MaCiąG, Uniwersytet ludowy-historia i specyfika, w: „Polski Uniwersytet Ludowy”, 3/42, Warszawa 1999, s. 97.

9 A. Bron-Wojciechowska, $d z$. cyt., s. 37 - 38. Grundtvig odbył podróże do Anglii w latach: $1829,1830,1831$.

10 E. MACIĄG, art. cyt., s. $98-99$.
} 
w 1864 r. został przeniesiony do Askov. Sięgając do historii pierwszych uniwersytetów ludowych trzeba też wspomnieć Krystena Kolda, założyciela uniwersytetu ludowego Ryslingen w 1851 roku. Krysten Kold wcielił na szeroką skalę ideę Grundtviga w życie ${ }^{11}$.

Idea ta i ta koncepcja szkoły ludowej uwzględniała fakt, że w każdym człowieku tkwi pierwiastek narodowości, ludowości. Zadaniem szkoły powinna być więc pielęgnacja tego właśnie pierwiastka. Stąd też duży nacisk kładło się na znajomość historii i literatury własnego narodu. Stanowiło to niezwykle ważny, nawet istotny element $\mathrm{w}$ grundtvigowskim systemie edukacji obywatelskiej. Ważna była tu również rola żywego słowa jako szansa lepszego przyswojenia treści z jednej strony i lepszej komunikacji międzyludzkiej, z drugiej. W tej koncepcji szkoły ludowej preferowana była i jest metoda oddziaływania bezpośredniego, co miało ścisły związek z koncepcją żywego słowa. „Szkoła dla życia”, jaką stanowiła instytucja uniwersytetu ludowego, miała służyć objaśnianiu życia, kreowaniu umiejętności wykorzystywania informacji do rozwiązywania problemów na różnych poziomach (indywidualny, lokalny, globalny) ${ }^{12}$.

Na takich właśnie podstawach krystalizuje się oryginalna instytucja kształcenia ludności wiejskiej, która szybko utorowała sobie drogę i zajęła znaczące miejsce w edukacji nie tylko duńskiej, ale także w wielu innych krajach, i to nie tylko europejskich. Według pierwotnych założeń szkoła skierowana była na potrzeby ludności wiejskiej. W związku jednak z pewnymi przeobrażeniami społeczno - gospodarczymi, jakie miały miejsce w Danii w przeciągu ostatniego stulecia, w chwili obecnej wszystkie grupy społeczne mają dostęp do kształcenia w duńskim uniwersytecie ludowym ${ }^{13}$.

Rekrutacja słuchaczy duńskich uniwersytetów ludowych z terenów zarówno wiejskich, jak i z miast jest współcześnie o tyle istotna, że uczelnia tego typu jest placówką konkurencyjną i od jej popularności oraz liczby słuchaczy zależy zarówno wysokość dotacji finansowych od państwa, jak i ogólna kondycja szkoły. Mimo licznych wewnętrznych przeobrażeń duńskiego Uniwersytetu Ludowego od czasu powołania tego typu placówki aż po współczesność, pewne elementy związane z tym typem instytucji wydają się być na tyle uniwersalne, że można je adaptować niezależnie od warunków społeczno - ekonomicznych, a propagowane treści są atrakcyjne niezależnie od charakteru regionu zamieszkania ${ }^{14}$.

Przede wszystkim Uniwersytet Ludowy jest instytucją zapewniającą stymulację rozwoju osobowościowego jednostki, zarówno poprzez propozycje programów kształcenia, jak i specyficzną w tym uniwersytecie atmosferę współpracy,

\footnotetext{
A. Niesio€owski, Formy i metody pracy oświatowej, Warszawa 1932, s. 32.

12 E. MACIĄG, art. cyt., s. 99.

13 Tamże.

14 Tamże, s. 100.
} 
wzajemnego zaufania, równego traktowania wszystkich uczestników kursu, bez względu na ich pochodzenie, wyznanie, wygląd zewnętrzny, czy też zdolności umysłowe. Te elementy były niezmiernie istotne w momencie tworzenia się pierwszych szkół ludowych. Chłopi duńscy pretendujący do uznania wówczas ich warstwy za pełnoprawną co do współdecydowania o procesach społeczno - polityczno - gospodarczych zachodzących w ich kraju potrzebowali instytucji pomocnej w ich dążeniach, a zarazem pozbawionej głównych elementów „tak znienawidzonej przez nich hierarchii społecznej”"15. Uniwersytet Ludowy był właśnie taką instytucją.

Wymienione wyżej elementy również współcześnie cieszą się dużą popularnością i to nie tylko w Danii. We współczesnym świecie ogromnej, często stresującej konkurencji wciąż istnieje duże zapotrzebowanie na możliwość harmonijnego rozwoju własnego, bez uciekania się do walki o pozycję w grupie. Najważniejsza staje się tu konkurencja z samym sobą, ze swoimi zdolnościami, ale też i ograniczeniami.

Duńskie uniwersytety ludowe znalazły trwałe miejsce w tradycji kulturalnej współczesnego świata. Dla wielu narodów i krajów są interesującym doświadczeniem, wzorem ideowym i pedagogicznym potwierdzeniem słuszności koncepcji Grundtviga, przykładem trafnego rozumienia prawidłowości rozwoju oświaty. Stanowią one bezcenne źródło inspiracji dla podejmowania i rozwiązywania problemów rozwoju kultury w wielu społeczeństwach ${ }^{16}$.

Założenia sformułowane przez Grundtviga pozwalają na ciągłe próby modernizowania tych placówek tak, że mogą one nadążać za nowymi potrzebami społecznymi. To chyba jest najistotniejsze w koncepcji duńskiego pedagoga, która przez swoją elastyczność oraz sięganie do potrzeb społecznych od 150 lat zachowuje swoją żywotność nie tylko w Danii, ale również w innych krajach skandynawskich. Odgrywała i odgrywa ciągle ważną rolę w pozyskiwaniu ludzi dla sprawy demokracji i kultury. Uniwersytety ludowe, jak pisze E. Maciąg, wniosły wielki wkład w rozwój kultury narodowej wielu krajów Europy ${ }^{17}$.

W tym właśnie znaczeniu były i są one ważnymi ośrodkami życia społecznego. Chociaż ich współczesne programy zarówno kulturalne, jak i o innym charakterze, są ściśle związane z zagadnieniami, którymi żyje cały współczesny świat, ich podstawowe cechy - atmosfera domu rodzinnego, osobisty kontakt nauczyciela z uczniem, otwarty dialog o świecie i działalności społecznej, podatność na zmiany w treściach i metodach kształcenia - pozostały niezmienne. Nadal, tak jak przed 150 laty, u podstaw ich działalności leży Grundtvigowska wiara w istotę tej placówki jako instytucji będącej szkołą życia ${ }^{18}$.

\footnotetext{
15 Tamże, s. 100.

16 Tamże, s. 101.

17 Tamże.

18 Tamże.
} 


\section{Uniwersytety Ludowe w Polsce i upowszechnianie wartości kultury wiejskiej}

Uniwersytety Ludowe jako instytucje oświaty dorosłych zostały twórczo zrealizowane na gruncie polskim w dużym stopniu dzięki Ignacemu Solarzowi ${ }^{19}$. $Z$ rodowodem, ideą i działalnością uniwersytetów ludowych zapoznał się on podczas swego pobytu w Danii. Po powrocie do kraju ten wybitny polski działacz ludowy i oświatowy zmodyfikował koncepcję uniwersytetów ludowych i dostosował ją do społecznych i kulturowych warunków w Polsce. Założone przez niego i prowadzone wspólnie z żoną Zofią Solarzową oraz z zespołem ofiarnych i ideowych współpracowników uniwersytety ludowe (w Szycach 1924 - 1931 i w Gaci Przeworskiej 1932 - 1939) odegrały ważną rolę społeczną w okresie międzywojennym i stały się one prototypem dla działających w Polsce po roku 1945, tego typu placówek oświatowych.

Szczególną zasługą tych instytucji oświatowych było dotarcie do tych grup mieszkańców wsi (szczególnie dorosłej młodzieży), które były spragnione wiedzy i dążyły do społecznego oraz kulturalnego awansu. Dla nich właśnie uniwersytet ludowy I. Solarza organizował kursy oświatowe, im umożliwiał zdobywanie wiedzy i utrwalanie swojej chłopskiej tożsamości oraz wielostronne rozwijanie własnej osobowości ${ }^{20}$. Cechą specyficzną tych placówek i powstałych później uniwersytetów ludowych było pełne zaangażowanie w trudny i złożony proces upowszechniania i pielęgnowania wartości kultury chłopskiej. Trzeba bowiem pamiętać, że na polską wieś bardzo silnie oddziaływały miejskie wzory kultury i tendencje do traktowania kultury chłopskiej jako „zacofanej” (w kategoriach jakiegoś „kulturowego skansenu”). I. Solarz i jego współpracownicy potrafili przeciwstawić się tej antyludowej tendencji do degradowania wartości kultury chłopskiej i zdołali ukazać jej niepowtarzalne piękno, mądrość i głęboki humanistyczny sens ${ }^{21}$.

Działalność tego typu placówek, obecnych i czynnych do dziś w naszym kraju, służyła i służy upowszechnianiu takich wartości kultury chłopskiej, jak: przywiązanie do ziemi, szacunek dla przyrody, pracowitość, kult życia rodzinnego, poczucie godności, miłość do Ojczyzny, głód wiedzy i dążenie do prawdy, poczucie sprawiedliwości, solidarność w walce z żywiołami, współczucie dla biednych i pokrzywdzonych, religijność oraz wytrwałość w trudnej i często dramatycznej walce o byt ${ }^{22}$.

\footnotetext{
19 Zob. m. in., L. Turos, Wychowawcze wartości kultury chlopskiej w ujęciu Ignacego Solarza i jego wychowanków, Siedlce 1982.

20 L. Turos, Rola Uniwersytetów Ludowych w upowszechnianiu wartości kultury chlopskiej, w: „Polski Uniwersytet Ludowy”, 3(30), Warszawa 1996, s. 23.

21 Tamże.

22 Tamże.
} 
Przywiązanie do ziemi kształtowały uniwersytety ludowe przez odkrywanie jej piękna, przydatności i żywotności (idea „matki - ziemi”), wykorzystując poezję, własne przeżycia wychowanków, informacje naukowe z zakresu nauk przyrodniczych. Przywiązanie do ziemi ukazywano jako stały składnik kultury chłopskiej, czerpania z niej tych źródeł energii (pożywienie), które były dla rolnika podstawą jego utrzymania. W tych placówkach miłość do ziemi ukazywano jako ten szczególny rodzaj związku chłopa ze środowiskiem naturalnym, w którym człowiek może odkrywać jej wielkość, piękno, pożytek i tkwiący w niej pierwiastek genialnej kreatywności. Przywiązanie do ziemi ukazywano na tle historii ruchu ludowego i walki chłopa o prawo do ziemi, do jej użytkowania i posiadania. Bardzo ważne miejsce $w$ programie dydaktyczno - wychowawczym uniwersytetów ludowych zajmuje miłość do Ojczyzny. Prezentowana w tych placówkach historia ruchów społecznych, zwłaszcza ruchu ludowego, zawiera także ważne informacje dotyczące udziału chłopów w walce o wyzwolenie narodowe, ich uczestnictwa w powstaniach narodowych. Dzięki temu placówki te przyczyniły się także, w pewnym stopniu, do spotęgowania udziału chłopów polskich w wojnie obronnej 1939 r. i walce konspiracyjnej z okupantem hitlerowskim ${ }^{23}$.

Historyczną zasługą uniwersytetów ludowych jest kształtowanie szacunku i zamiłowania do pracy na roli, postrzegania jej funkcji w samorealizacji chłopów, uświadamiania rolnikom ogromnej społecznej, ekonomicznej i kulturotwórczej roli ich działalności zawodowej. Praca była i jest traktowana w uniwersytetach ludowych jako jedna z najwyższych wartości kultury chłopskiej, narodowej i ogólnoludzkiej; jako ten rodzaj działalności ludzkiej, która nadaje egzystencji człowieka sens, wielkość a nawet świętośćc 24 .

Znaczące miejsce w systemie edukacyjnym uniwersytetów ludowych zajmowała zawsze problematyka życia rodzinnego. Placówki te utrwalały i utrwalają, zakorzenione głęboko w kulturze chłopskiej, przekonanie o tym, że rodzina jest jedną z najbardziej humanistycznych instytucji społecznych, w których jednostka i grupa może zaspokajać swoje potrzeby zarówno materialne, jak i duchowe. Placówki te ukazują rodzinę jako instytucję wychowawczą, ale także jako związek ludzi złączonych miłością, sakramentem i zobowiązaniem wobec prawa. Rodzina jest też przedstawiana jako zespół, który wspólnie pracuje (indywidualne gospodarstwa rolne) oraz jako środowisko kulturotwórcze, które tworzy swój własny styl życia, obyczaje i podkulturę życia rodzinnego ${ }^{25}$.

Uniwersytety ludowe uwrażliwiały młodzież na taką wartość kultury chłopskiej, jaką jest dążenie do prawdy i swoisty głód wiedzy. Nie będzie przesadą stwierdzenie, ze uniwersytety ludowe przyczyniły się do awansu społecznego

\footnotetext{
23 Tamże, s. 24- 25.

24 Tamże, s. 25.

25 Tamże, s. 26.
} 
i kulturalnego wsi przede wszystkim dzięki rozbudzeniu potrzeby samokształcenia, uczenia się, pracy nad sobą. Dzięki tym placówkom ze świadomości i mentalności mieszkańców wsi zostały w pewnym stopniu wyeliminowane przesądy społeczne i obyczajowe, wynikające z niewiedzy, czasem umysłowego lenistwa, braku krytycyzmu, nieumiejętności samodzielnego myślenia, ulegania przestarzałym wyobrażeniom o świecie ${ }^{26}$.

Uniwersytety ludowe katolickie uczestniczyły także aktywnie i twórczo w procesie ukazywania takiej wartości kultury chłopskiej, jaką jest religijność, ale rozumiana nie tylko jako uczestnictwo (często bierne) w obrzędach i zwyczajach religijnych, lecz jako głęboko rozumiana świadoma służba Bogu. Dzięki temu kontynuowały one tradycję chrześcijańskiej kultury polskiej, w której Bóg, człowiek i Ojczyzna zajmują naczelne miejsce ${ }^{27}$.

Stosowane w tych placówkach takie metody, jak wykłady, swobodna dyskusja, analiza wybranych materiałów badawczych, lektura prac naukowych, czytelnictwo literatury pięknej umożliwiały i umożliwiają wychowankom wyrobienie sobie własnego racjonalnego poglądu na ideały i społeczne wcielenia różnych koncepcji sprawiedliwości, wpływają one na rozwój wyobraźni oraz kreowanie własnej wizji społecznego $\mathrm{ladu}^{28}$.

\section{Podsumowanie}

W tradycji polskich uniwersytetów ludowych mamy bardzo nowoczesną ideę, teorię i zarazem metodę wychowania, pedagogiki, która sprawdza się w praktyce w najcięższych nawet sytuacjach kryzysowych ${ }^{29}$. Dotyczy to nie tylko I. Solarza i jego osiągnięć, choć wielkich, lecz całego dorobku polskich uniwersytetów ludowych. Jest co kontynuować w warunkach, które przyszły, a także w tych, które przychodzą, w dobie naszej integracji z innymi państwami Europy. Sceptycy tej koncepcji - euroentuzjaści powiedzą zapewne, iż nie ma i nie będzie na to zapotrzebowania, że lepiej zakładać kluby, dyskoteki i puby, bo to jest przyszłość młodzieży nie tylko miejskiej, ale także i wiejskiej ${ }^{30}$. Nie widzą oni, jak pisze Zofia Kaczor - Jędrzycka, ze zapotrzebowanie na kontynuację, na kultywowanie tych wartości już narasta, tylko jest tłumione z różnych powodów. Kontynuacja jest bowiem, jak pisze, „pewną dziejową prawidłowością"’31.

\footnotetext{
26 Tamże, s. 27.

27 Tamże.

28 Tamże, s. 28.

29 Z. Kaczor-JęDrzycKa, Kontynuacja tradycji Polskich Uniwersytetów Ludowych na progu XXI wieku, w: „Polski Uniwersytet Ludowy”, 4/39, Warszawa 1998, s. 17 - 24.

30 Zob. tamże, s. 20.

31 Tamże, s. 21.
} 
Dzięki upowszechnianiu tradycyjnych i współczesnych wartości kultury chłopskiej współczesne uniwersytety ludowe mogłyby przyczyniać się do integracji kultury polskiej z kulturą europejską. Z jednej strony wpływałyby one pozytywnie na utrzymanie się kulturowej odrębności Polaków, gdyż ta swoistość kultury narodowej ma podstawę w oryginalności kultury chłopskiej. Upowszechnianie kultury chłopskiej przez wspólczesne uniwersytety ludowe służyłoby właśnie umocnieniu niezależności kulturowej narodu polskiego oraz zachowaniu jego niepowtarzalności i zdolności do rozwoju ${ }^{32}$.

Upowszechnianie przez uniwersytety ludowe wartości kultury chłopskiej pomogłyby także w głębszym zrozumieniu przeżyć i przyswojeniu wybranych wartości kultury europejskiej. Do takich wartości należą niewątpliwie: tolerancja światopoglądowa i religijna, uznanie prawa człowieka do zachowania swojej indywidualności, rozwój osobowości, wolność polityczna narodów, wolność słowa, humanizm, demokracja. Upowszechnianie tych wyżej wymienionych wartości kultury chłopskiej sprzyjałoby poznaniu i otwarciu się na te właśnie wartości kultury europejskiej, które mieszczą się w szeroko rozumianym pojęciu praw człowieka.

Chłopi walcząc o swoje prawo do godności, do decydowania o swoim losie, do udziału w życiu społeczeństwa, narodu i państwa, walczyli równocześnie o podstawowe prawa człowieka. Pojęcie godności człowieka jest też podstawowym składnikiem europejskiego humanizmu ${ }^{33}$. Zrozumienie pojęcia godności funkcjonującego w polskiej chłopskiej kulturze umożliwia głębsze poznanie tej wartości w jej europejskim wydaniu. Pojęcie losu chłopskiego może być więc bardzo pomocne w rozumieniu europejskiej koncepcji losu człowieka.

Upowszechnianie przez uniwersytety ludowe wartości kultury chłopskiej $z$ jednej strony uchroni polską wieś przed bezkrytycznym przejmowaniem wszelkich nowinek kultury europejskiej, przed jej apologetyczną fetyszyzacją ${ }^{34}$ a $\mathrm{z}$ drugiej strony ułatwi poznanie tych jej idei i doświadczeń, które odzwierciedlają jej najwybitniejsze osiągnięcia umysłowe, artystyczne i społeczne jej twórców ${ }^{35}$.

L. Turos, art. cyt., s. 29.

3 Zob. Tamże, s. 29.

34 Pejoratywne: „Otaczanie jakichś przedmiotów lub zjawisk irracjonalnym kultem lub przecenianie ich roli." (Słownik wyrazów obcych, PWN, Warszawa 2004, s. 289.

35 Zob. szerzej m. in. L. Turos, Patrzeć szeroko i daleko. Dziedzictwo pedagogiczne Ignacego Solarza, Warszawa 1983. 


\title{
The role of People's Universities in ecological education of country youth
}

\begin{abstract}
SUMMARY
This article concerns widely perceived ecological education being provided among country youth by People's Universities. Their homeland is Denmark and M. F. S. Grundvig is concerned to be their father. He observed English educational system and the way of education with the usage of boarding schools and then he transmitted it to Denmark, where at the end of the $18^{\text {th }} \mathrm{c}$. and at the beginning of the $19^{\text {th }}$ century the role of peasants, who reached for power and had their own farms, increased. Therefore, there was a necessity to create an integrated educational system for those people.

This way of educating was then carried to Poland by Ignacy Solarz and his wife Zofia Solarzowa - that took place in the mid- $20^{\text {th }}$ century. A special tribute of these educational institutions was reaching those country groups of people who were hungry for knowledge and social advance. People's Universities had and have ecological education established in their educational programme. However, this education concerns integrated, harmonic and balanced development of the human being, since, if ecology means the knowledge about the environment, it is the human being that should be the most important, that should be the subject.

In this system of educating one is not only concerned in gaining the knowledge, but also in ability to pass the gained knowledge, expressing one's opinions, ability to make relations with people and with the world. This system is about the most integrated development of a student's personality. The ecological education must not limit itself just to care about the nature, but it should also take into consideration the human's psychology, environment in which one was brought up and also the values with which one was fed. That is why this widely taken ecology should not omit religious, cultural and patriotic values. And People's Universities draw their attention to this kind of values.
\end{abstract}

